\title{
Generation of a novel polysaccharide by inactivation of the aceP gene from the acetan biosynthetic pathway in Acetobacter xylinum
}

\author{
K. J. Edwards, † A. J. Jay, I. J. Colquhoun, V. J. Morris, M. J. Gasson \\ and A. M. Griffin
}

Author for correspondence: A. M. Griffin. Tel: +44 1603 255354. Fax: +44 1603507723. e-mail : annette.griffin@ bbsrc.ac.uk

Institute of Food Research, Norwich Laboratory,

Norwich Research Park, Colney, Norwich, NR4 7UA, UK

\begin{abstract}
The acetan biosynthetic pathway in Acetobacter xylinum is an ideal model system for engineering novel bacterial polysaccharides. To genetically manipulate this pathway, an Acetobacter strain (CKE5), more susceptible to gene-transfer methodologies, was developed. A new gene, aceP, involved in acetan biosynthesis was identified, sequenced and shown to have homology at the amino acid level with $\beta$-D-glucosyl transferases from a number of different organisms. Disruption of aceP in strain CKE5 confirmed the function assigned above and was used to engineer a novel polysaccharide with a pentasaccharide repeat unit.
\end{abstract}

Keywords: Acetobacter xylinum, aceP gene, acetan, EPS biosynthesis, novel EPS

\section{INTRODUCTION}

Microbial exopolysaccharides (EPSs) are long-chain, high-molecular-mass polymers that are secreted into the environment by a large variety of different bacteria. These polymers are believed to play a protective role in the native state, and after isolation can be dissolved/ dispersed in water to give interesting thickening, gelling and emulsifying effects: properties which are indispensable tools in the food and many other industries (Roller \& Dea, 1992; Sutherland, 1998). Many EPSs secreted by bacteria are regular structures composed of complex chemical repeat units. These repeat units can contain a number of different sugars linked in a variety of ways; the structure can be branched or multibranched, and may be decorated with non-carbohydrate substituents (Kenne \& Lindberg, 1983; Lindberg, 1990). It is widely known that the functional properties of an EPS are determined by its primary structure, which dictates the subsequent folding and association under various environmental conditions. To assess the contribution of each sugar unit/linkage/substituent to the polysaccharide functionality it is desirable to engineer

† Present address: Central Public Health Laboratory, 61 Colindale Avenue, Colindale, London, NW9 5HT, UK.

Abbreviations: $C T A B$, cetyltrimethylammonium bromide; EPS, exopolysaccharide; PMA, partially methylated alditol acetate.

The EMBL accession number for the sequence reported in this paper is Y18467. novel polymers which are variants of the common structure (Griffin et al., 1995). The acetan biosynthetic pathway in Acetobacter xylinum is an ideal model system for engineering novel bacterial polysaccharides for the following reasons. Firstly, the biochemical pathway for acetan biosynthesis has been elucidated and shown to be similar to that of xanthan biosynthesis in Xanthomonas campestris (de Iannino et al., 1988). Secondly, acetan is structurally related to the commercially important polymer, xanthan (Fig. 1). It also has an advantage over xanthan for engineering studies because the repeat unit contains seven sugars (two more than xanthan), thereby increasing the scope for variation. Finally, many of the genes involved in acetan biosynthesis have been cloned and sequenced from the bacterial chromosome (Griffin et al., 1996a, b, 1997a, b). It is envisaged that novel polymers could be produced either by inactivation of a selected sugar-transferase gene or by heterologous expression of transferase genes from other bacterial systems. In previous studies, random mutagenesis strategies were used to identify strains producing variants of the wild-type acetan and xanthan EPS repeat unit (MacCormick et al., 1993; Betlach et al., 1987; Hassler \& Doherty, 1990). These data confirm that the bacterial biosynthetic machinery can correctly polymerize and export variant polysaccharide structures.

In this paper we report the identification and sequencing of aceP, a new gene encoding a glycosyl transferase involved in acetan biosynthesis. We report the de- 
(a)

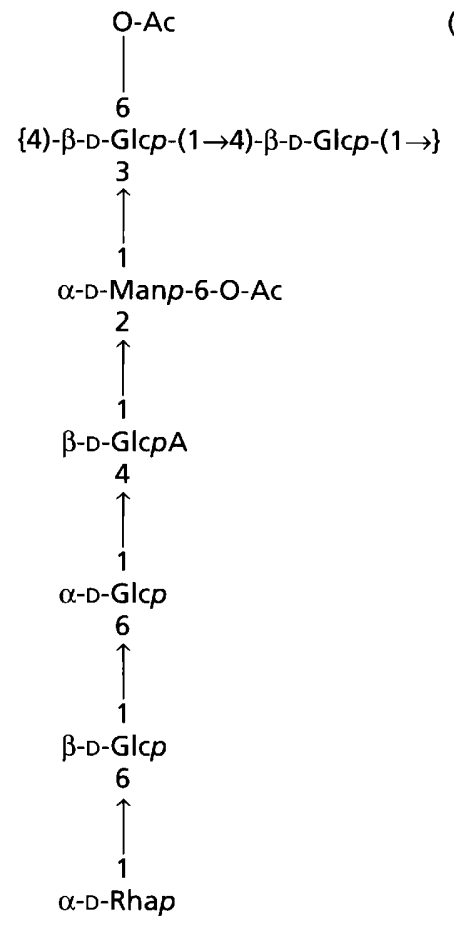

(b)

(c)

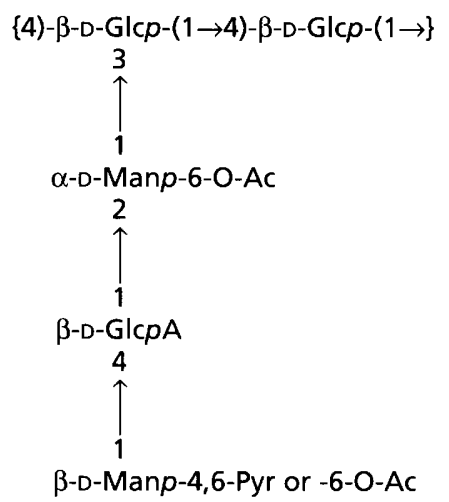

Fig. 1. Structure of the repeat units of (a) acetan produced by strains of $A$. xylinum and (b) xanthan, produced by $X$. campestris and (c) P2 polysaccharide produced by the mutant strain of $A$. xylinum. Glc, glucose; Man, mannose; GlcA, glucuronic acid; Rha, rhamnose; O-Ac, O-acetyl group; Pyr, pyruvate ketal. A ' $p$ ' after the sugar abbreviation indicates the pyranose form. Base label substituents are omitted from the structure shown in (c).

velopment of an Acetobacter strain that is more amenable to electrotransformation and the disruption of the aceP gene in this strain to engineer a novel polysaccharide with a pentasaccharide repeat unit.

\section{METHODS}

DNA manipulations. DNA from plasmid pAG18 (Griffin et al., 1997a) was prepared by centrifugation through caesium chloride/ethidium bromide gradients as described by Sambrook et al. (1989). Double-stranded DNA sequencing was performed on plasmid DNA using an ABI 373A automated sequencer. Sequence data were analysed on a VAX 4600 using the computer analysis package GCG version 8.0 (Devereux et al., 1984), CluSTAL (Higgins, 1994), FASTA, TFASTA (Pearson, 1994) and BLAST (Altschul et al., 1990). PCR primers were designed with the aid of the oligo computer program (National Biosciences) and synthesized on an $\mathrm{ABI}$ 394 DNA Synthesizer (Perkin Elmer). PCR amplifications were performed as described previously (Griffin et al., 1996b). The nucleotide sequences of primers were as follows: M13F (5'-CCCAGTCACGACGTTGTAAAACG-3'), M13R (5'AGCGGATAACAATTTCACACAGGA-3'), a3 (5' -TTCCCATGTCCGTCAGTC-3') and a 4 (5'-AGCCTGCGCCTGAGTGCC-3').

Plasmids, bacterial strains and culture conditions. The plasmid vectors pAG18 $\left(\mathrm{amp}^{\mathrm{R}}\right.$ ) (Griffin et al., 1997a), pUCD2 $\left(\mathrm{amp}^{\mathrm{R}} \mathrm{kan}^{\mathrm{R}} \operatorname{tet}^{\mathrm{R}}\right.$ ) (Close et al., 1984) and pCR2.1 $\left(\mathrm{amp}^{\mathrm{R}}\right.$ ) (Invitrogen) were used. A. xylinum strains C1 and CKE5 were grown in HS medium (Hestrin \& Schramm, 1954) and incubated at $30^{\circ} \mathrm{C}$ for $3 \mathrm{~d}$. Broth cultures were shaken at 200 r.p.m. When required, antibiotics were added as follows : $4 \mu \mathrm{g}$ tetracycline $\mathrm{ml}^{-1}, 20 \mu \mathrm{g}$ ampicillin $\mathrm{ml}^{-1}$. Incubation for up to $10 \mathrm{~d}$ was required in the presence of antibiotic selection.

Electroporation of CKE5. A. xylinum was grown in HS broth at $30^{\circ} \mathrm{C}, 300$ r.p.m. until an $\mathrm{OD}_{600}$ of $0.4-0.5$ was reached. Cells were harvested, washed twice with ice-cold milliQ water and resuspended in $100 \mu \mathrm{l} 10 \%(\mathrm{v} / \mathrm{v})$ glycerol. Plasmid DNA
$(5 \mu \mathrm{g})$ was added to $40 \mu \mathrm{l}$ aliquots of cells (in $0 \cdot 1 \mathrm{~cm}$ cuvette). Using a Gene pulser apparatus (Bio-Rad laboratories), pulses of $1.8 \mathrm{kV}, 200 \Omega$ and $25 \mu \mathrm{F}$ were applied, then $960 \mu \mathrm{l}$ ice-cold HS broth was added immediately. Cells were incubated at $30^{\circ} \mathrm{C}$ for $3 \mathrm{~h}$ to allow plasmid expression, then diluted and plated onto $\mathrm{HS}$ agar plates containing appropriate antibiotics. Plates were incubated at $30{ }^{\circ} \mathrm{C}$ for $3-10 \mathrm{~d}$.

Construction of an $A$. xylinum strain with high electrotransformation frequencies. Strain $\mathrm{C} 1$ of $A$. xylinum was mutagenized by exposure to $0.04 \%$ methane sulfonic acid ethyl ester at $37^{\circ} \mathrm{C}$ for $45 \mathrm{~min}$. This procedure resulted in a $1 \%$ survival rate of cells. These were electrotransformed with the plasmid vector pUCD2, and one transformant, CK, was selected for a plasmid-curing procedure, which was carried out as follows: cultures in $10 \mathrm{ml}$ HS broth containing $10 \mu \mathrm{g}$ acriflavin $\mathrm{ml}^{-1}$ were incubated at $30^{\circ} \mathrm{C}$ for $24 \mathrm{~h}$ with agitation, then plated onto HS plates and incubated at $30^{\circ} \mathrm{C}$ for $3 \mathrm{~d}$. When subsequently tested, $90 \%$ of colonies obtained had lost plasmid-associated antibiotic resistance and were therefore 'cured' of the plasmid. The electroporation frequencies of six individual 'cured' isolates (CKE1 to CKE6) were tested.

Construction of pKE23. pCR2.1 $\left(\mathrm{amp}^{\mathrm{R}} \mathrm{kan}^{\mathrm{R}}\right)$ does not replicate in A. xylinum CKE5 and was used to construct a

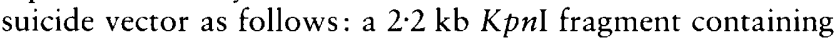
the tetracycline-resistance gene from pKT1a (J. Kok, pers. comm.) was cloned into the KpnI site of pCR2.1 to generate pKE14 $\left(\right.$ tet $\left.^{\mathrm{R}} \mathrm{amp}^{\mathrm{R}} \mathrm{kan}^{\mathrm{R}}\right)$. Primers a1 $\left(5^{\prime}\right.$-GATGACTGTTCCACCGAC-3') and a2 (5'-AGCCGCTGCAGTCCCTCG$\left.3^{\prime}\right)$ were used to amplify a $700 \mathrm{bp}$ fragment of the aceP gene from pAG18 using the PCR conditions described previously (Griffin et al., 1996b) except that 1 unit Dynazyme (Flowgen) was used and cycling conditions were 25 cycles of $94{ }^{\circ} \mathrm{C}$ for 1 $\min , 50^{\circ} \mathrm{C}$ for $1 \mathrm{~min}$ and $72{ }^{\circ} \mathrm{C}$ for $1 \mathrm{~min}$. The $700 \mathrm{bp} \mathrm{PCR}$ product obtained was purified, blunt ended (Sambrook et al., 1989) and subsequently cloned into SpeI-digested blunt-ended pKE14 to generate pKE23.

Preparation, purification and chemical analysis of polysaccharide. Polysaccharide was harvested from the P2 strain 
and purified by precipitation with cetyltrimethylammonium bromide (CTAB) as described previously for A. xylinum strains (MacCormick et al., 1993). No attempt has been made to optimize growth conditions or to maximize polysaccharide production. Total carbohydrate content of crude and purified polymer from strain P2 was estimated colorimetrically by the phenol/sulphuric acid method (Dubois et al., 1956), calibrated using glucose. The presence and level of uronic acid was determined using the 3-hydroxybiphenyl method (FilisettiCozzi \& Carpita, 1991), calibrated using glucuronic acid. The presence of rhamnose was determined using the thiocarbamide method (Dische \& Shettles, 1948; Baird \& Smith, 1989). Neutral sugar composition was determined by subjecting the purified or crude $\mathrm{P} 2$ polysaccharide to acid hydrolysis in $2 \mathrm{M}$ trifluoroacetic acid and derivatization to alditol acetates (MacCormick et al., 1996). The linkage sites of all sugars were determined by methylation analysis as follows: the polymer was methylated (MacCormick et al., 1993), extracted into $\mathrm{CHCl}_{3} / \mathrm{CH}_{3} \mathrm{OH}(1: 1)$, split into three parts and vacuum dried over $\mathrm{P}_{2} \mathrm{O}_{5}$ overnight. The first part was reduced with lithium triethy lborodeuteride in tetrahydrofuran ('Super Deuteride') at $64^{\circ} \mathrm{C}$. for $4 \mathrm{~h}$ (York et al., 1985). Excess reagent was treated with 2-propanol, water, then $1 \mathrm{M} \mathrm{H}_{3} \mathrm{PO}_{4}$ to $\mathrm{pH} \mathrm{5}$, followed by filtration on glass-fibre paper and washing with $\mathrm{CHCl}_{3}$ / $\mathrm{CH}_{3} \mathrm{OH}(1: 1)$. After drying, the first part (carboxy-reduced) and the second part of the methylated polymers were hydrolysed with trifluoroacetic acid and converted to partially methylated alditol acetates (PMAAs) as described previously (MacCormick et al., 1996). The third portion of the methylated polymer was subjected to reductive cleavage using triethylsilane/trimethylsilyl trifluoromethanesulfonate/ dichloromethane (Rolf et al., 1985) and acetylated with acetic anhyride/acetic acid/N-methylimidazole $(3: 0.5: 0.5 \mathrm{ml})$ at $30^{\circ} \mathrm{C}$ for $30 \mathrm{~min}$. This was extracted with water/dichloromethane in the usual way to yield partially methylated anhydroalditol acetates. The PMAAs and anhydroalditol derivatives were analysed by GC-MS as described previously (MacCormick et al., 1996). A mixture of external PMAA standards for each sugar was prepared by deliberate: undermethylation of the methyl glycosides (Doares et al., 1991). 1,5-anhydroglucitol and 1,5-anhydromannitol were synthesized by the method of Ness et al. (1950). These were similarly undermethylated and acetylated to produce mixtures of standards. The identities of the PMAAs and partially methylated anhydroalditol acetates were confirmed from their electron-ionization mass spectra (Carpita \& Shea, 1989; Gray, 1990). Polysaccharide harvested from strain CKE5 was prepared without CTAB precipitation. This was analysed as described above except that the reductive cleavage analysis was omitted.

\section{RESULTS}

\section{Development of a strain of $A$. xylinum with high electrotransformation frequencies}

Strain C1 of A. xylinum could not be transformed by either chemical-based protocols (Fukaya et al., 1985) or by conjugation using broad-host-range mobilizable vectors (Valla et al., 1986; Inoue et al., 1985). Transformation frequencies obtained following electroporation using previously published protocols (Hall et al., 1992; Wong et al., 1990) and our own optimized protocol (see Methods) gave low and unreliable frequencies (max frequency $10^{2}$ c.f.u. $\mu \mathrm{g}^{-1}$ DNA) (data not presented). Methane sulfonic acid ethyl ester treat-

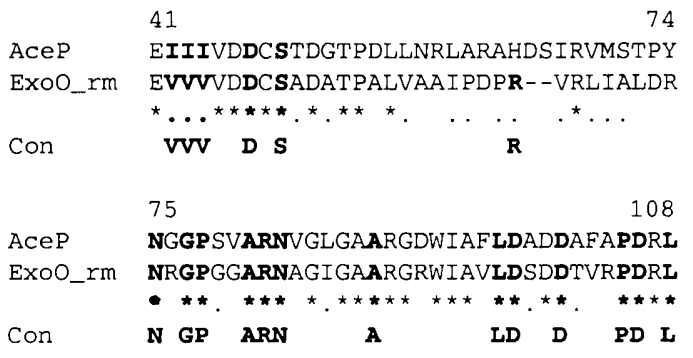

Fig. 2. An alignment of the regions of the amino acid sequences of AceP from $A$. xylinum and ExoO from Sinorhizobium meliloti (Becker et al., 1993). The conserved sequence motif found in the $\mathrm{N}$-terminal region of a number of $\beta$-glycosyl transferases (Becker et al., 1998) is shown in bold. Asterisks (*) are used to identify positions of identity and dots are used to identify positions of conservative replacements.

ment of strain $\mathrm{C} 1$ and a plasmid-curing regime were used to isolate six new strains, CKE1 to CKE6. The electroporation frequencies of these strains were tested and reproducibly found to be as follows: CKE1, CKE2 and CKE4 had frequencies of $10^{4}$ transformants $\mu \mathrm{g}^{-1}$ DNA, CKE3 and CKE6 had frequencies of $10^{5}$ transformants $\mu \mathrm{g}^{-1}$ DNA, while CKE5 had a transformation frequency of $10^{6}$ transformants $\mu \mathrm{g}^{-1}$ DNA.

\section{Sequence analysis of the ace $P$ gene}

The identification and cloning of a plasmid clone, pAG18, containing genes involved in acetan biosynthesis has previously been reported (Griffin et al., 1997a). The nucleotide sequence of a 1174 bp region of pAG18 was determined and is available from the EMBL database under accession number Y18467. Computer analysis of this region revealed the presence of an ORF that showed strong conformity to the Acetobacter codon usage table (not shown). This ORF, which was designated aceP, encodes a protein of 321 aa with a molecular mass of $35.37 \mathrm{kDa}$. There are two potential start codons for aceP; we assume the first ATG represents the actual start codon, since it is preceded at a reasonable distance by a strong potential ribosome-binding site (position 20-23) which has homology to the 3' end of Acetobacter $16 \mathrm{~S}$ rRNA sequences (Sievers et al., 1994). A stem-loop structure was detected downstream of aceP, at positions 1054 to 1080 .

A comparison of the deduced amino acid sequence of aceP to the sequences in the EMBL/GenBank/DDBJ databases revealed pronounced homology with glycosyl transferases from a variety of different organisms: for example, it had $56.54 \%$ similarity $(33.98 \%$ identity) over the entire length of the 321 aa protein to ExoO from Sinorhizobium meliloti (previously Rhizobium meliloti) strain 2011 (Fig. 2) (Becker et al., 1993), 56.62\% similarity (33.44\% identity) over 316 residues to ExoO from Sinorhizobium fredii strain USDA208 (accession number AF061245), $54.54 \%$ similarity ( $31.49 \%$ identity) over a length of 320 residues to ExoU from Sinorhizobium meliloti (Glucksmann et al., 1993) and 

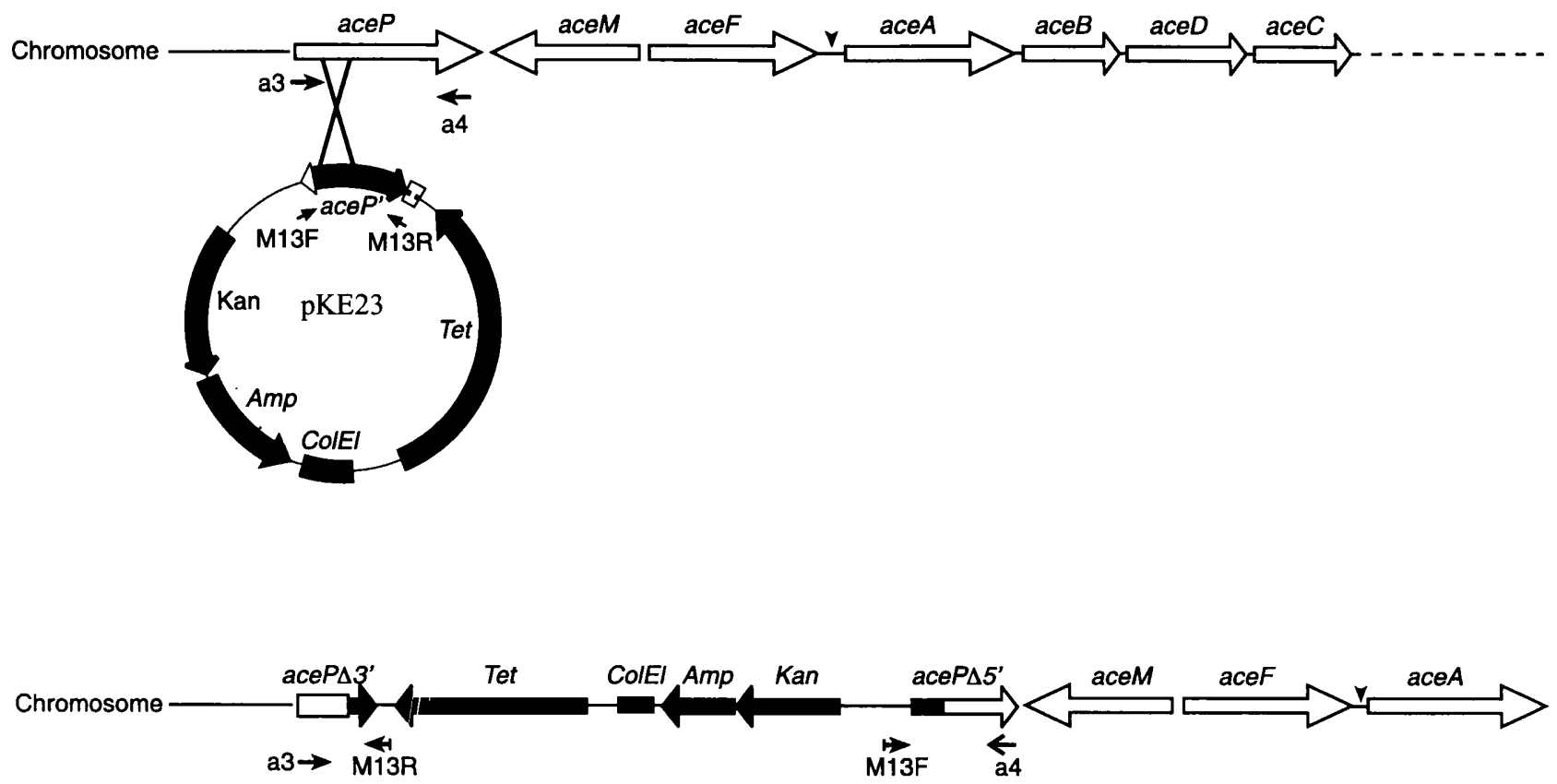

Fig. 3. Strategy for the construction of an ace $P^{-}$strain of $A$. xylinum. At the top, the plasmid pKE23, described in Methods is drawn schematically. The truncated ace $P$ gene fragment was used for integration into the $A$. xylinum genome by a single cross-over. Structure of the chromosomal acetan gene cluster (region of ace $P$ gene) before integration is shown above the plasmid, while the structure after integration is shown below (the genes downstream of ace $A$ are present, but not shown here). Location and transcription of genes from the plasmid and the chromosome are represented by large arrows and the small vertical arrowhead upstream of ace $A$ indicates the position of a putative promoter. The chromosomal genes have been previously reported to encode the following activities: ace $M$, an UDPglucose dehydrogenase (Griffin et al., 1997a); aceF, a bifunctional enzyme with phosphomannose isomerase and GDPmannose pyrophosphorylase activities (Griffin et al., 1997b); aceA, ace B and aceC, transferase I, II and III of the acetan pathway, respectively, and $a c e D$ a function required for polysaccharide polymerization and/or export (Griffin et al., 1996a, b).

$52.54 \%$ similarity $(23.73 \%$ identity) over 309 residues to Cps14J from Streptococcus pneumoniae (Klokman et al., 1997). Interestingly, AceP displayed lower homology to AceA ( $48 \%$ similarity) and AceB $(50.44 \%$ similarity), which are two glucosyl transferases involved in acetan biosynthesis in A. xylinum (Griffin et al., 1996a, b). ExoO and ExoU have been demonstrated to act as $\beta$-Dglucosyl $1 \rightarrow 6$ transferases in the pathway for the biosynthesis of succinoglycan in Sinorhizobium meliloti (Reuber \& Walker, 1993), while AceA and AceB are predicted to catalyse the transfer of $\beta$-D-glucosyl $1 \rightarrow 4$ linkages. Therefore it is likely that AceP catalyses the transfer of a $\beta$-D-glucose $1 \rightarrow 6$ linked glucose and, since only one $\beta$-D-glucosyl $1 \rightarrow 6$ linkage exists in the acetan repeat unit (Fig. 1), AceP is predicted to represent transferase 6 of the acetan pathway. A conserved sequence motif found in the $\mathrm{N}$-terminal region of $\beta$ glucosyl transferases (Becker et al., 1998) is located in the N-terminal region of AceP (Fig. 2).

\section{Disruption of the aceP gene}

To confirm the function predicted for AceP and to specifically engineer a novel acetan-based polymer, disruption of aceP was carried out using a truncatedgene strategy (see Methods and Fig. 3). A. xylinum CKE5 was transformed with pKE23 DNA and tetracycline-resistant transformants were selected. As this plasmid is unable to replicate in A. xylinum, tetracycline-resistant colonies represent strains in which plasmid DNA has integrated into the chromosome by a homologous-recombination event. Twenty-one transformants were selected and shown to be tetracycline and ampicillin resistant. In two selected strains, P2 and P3, interruption of the aceP gene was confirmed by PCR using primers a 3 and a4, which anneal to sites on the chromosome outside the fragment of aceP cloned in pKE23, in combination with the primers M13F and M13R (Fig. 3). Using chromosomal DNA as a template with primers a3 and a4, a 940 bp fragment was amplified from CKE5 DNA while no product was obtained from P2 and P3 DNA. A 900 bp fragment was amplified from chromosomal DNA from strains $\mathrm{P} 2$ and $\mathrm{P} 3$ using primer pairs a3+M13R and a4+M13F. No product was amplified from CKE5 DNA with these primer pairs. These data confirm that pKE23 had integrated into the chromosome resulting in a disruption of the aceP gene of A. xylinum CKE5.

\section{Chemical analysis of EPS from strain P2}

The yields of lyophilized, crude polysaccharide from strains P2, CKE5 and C1 of A. xylinum were $3.96 \mathrm{~g} \mathrm{l}^{-1}$, $4.62 \mathrm{~g} \mathrm{l}^{-1}$ and $4.38 \mathrm{~g} \mathrm{l}^{-1}$, respectively. It is noticeable that 
the yield from the mutant $\mathrm{P} 2$ is not drastically reduced compared to that of the CKE5 parent strain. This is contrary to the common belief that disruption of biosynthetic genes drastically reduces the level of polysaccharide produced. This conclusion is largely based on the analysis of mutants produced by random mutagenesis strategies. Identification of mutants in such strategies usually relies on screening for individuals with a small colony morphology and/or a reduced mucoid character. Thus, the choice of screening conditions may force the selection of strains with multiple mutations, i.e. a reduced level of polysaccharide production in addition to disruption of the polysaccharide-assembly process. In the present case, the targeting of a particular gene appears to have only affected polysaccharide assembly and not the level of polysaccharide production.

The lyophilized, crude P2 polysaccharide preparation was found to contain $8.2 \%$ carbohydrate and only $0 \cdot 86 \%$ uronic acid. The 6 -deoxyhexose test was negative, indicating the absence of any detectable rhamnose. The neutral sugar analysis showed the presence of glucose and mannose in the ratios $1 \cdot 5: 1 \cdot 0$. The analysis of the crude polysaccharide from P2 was compared with that of the parent strain CKE5 which was used as a control. The crude preparation from CKE5 contained $19.7 \%$ carbohydrate and $2.6 \%$ uronic acid, and a positive 6-deoxyhexose test indicated the presence of rhamnose. Linkage analysis of the crude preparations from strains C1 (cellulose-, $\operatorname{acetan}^{+}$) and CKE5 confirmed that the CKE5 parental strain produced acetan: the linkage analysis showed the presence of $t$-rhamnose; 1,2-mannose; 1,6-glucose; 1,4-glucose; 1,3,4-glucose plus t-mannose and 1,2,6-mannose. The t-rhmnose; $1,2-$ mannose ; 1,6-glucose; 1,4-glucose and 1,3,4-glucose are, together with the positive test for uronic acid, consistent with the acetan structure. Linkage analysis after carboxy reduction revealed the presence of additional deuterated 1,4,6-glucose indicating the presence of 1,4-glucuronic acid in the original $\mathrm{C} 1$ and CKE 5 extracts. These studies confirmed the presence of acetan. The additional linkages ( $t$-mannose, 1,2,6-mannose plus some 1,2mannose) are due to the presence of a neutral branched mannan. These contributions are reduced after CTAB purification of the crude polysaccharide, a procedure which preferentially isolates charged polysaccharides from neutral polysaccharides.

Having established that the CKE5 parent strain produces acetan it was then possible to analyse the product of the new P2 strain to assess the effect of genetic modification on the structure of the polysaccharide produced. On purification by CTAB precipitation, the crude polysaccharide from P2 $(1.13 \mathrm{~g})$ yielded $75 \mathrm{mg}$ of lyophilized material. This contained $82 \pm 2 \%$ (w/w) carbohydrate (as glucose) and $27 \%$ uronic acid. The presence of the uronic acid leads to an underestimate of the total level of carbohydrate by about $20 \%$ because glucuronic acid has a lower response factor than glucose. Thus, the CTAB preparation was almost pure polysaccharide. Neutral sugar analysis showed an increase in the ratio of glucose: mannose to $3 \cdot 9: 1 \cdot 0$. The methylation analysis
Table 1. Linkage analysis of extracellular polysaccharides from $A$. xylinum $\mathrm{P} 2$.

CTAB, CTAB purified; C-red, carboxy reduced; red.cl, reductive cleavage analysis.

\begin{tabular}{|lcccc|}
\hline $\begin{array}{l}\text { Linkages } \\
\text { Molar ratio in ... }\end{array}$ & Crude & CTAB & $\begin{array}{c}\text { CTAB } \\
\text { C-red }\end{array}$ & $\begin{array}{c}\text { CTAB } \\
\text { red.cl* }\end{array}$ \\
\hline t-Rha & - & - & - & - \\
t-Man & $1 \cdot 9$ & - & - & - \\
t-Glc & $1 \cdot 4$ & $1 \cdot 8$ & $1 \cdot 8$ & $1 \cdot 3$ \\
1,2-Man & $1 \cdot 7$ & $0 \cdot 83$ & $2 \cdot 5$ & $1 \cdot 6$ \\
1,4-Glc & $1 \cdot 0$ & $1 \cdot 0$ & $1 \cdot 0$ & $1 \cdot 0$ \\
1,3,4-Glc & $0 \cdot 69$ & $0 \cdot 50$ & $0 \cdot 68$ & $1 \cdot 1$ \\
1,4-GlcA & - & - & $0 \cdot 95$ & $2 \cdot 1$ \\
1,2,6-Man & $0 \cdot 87$ & - & - & - \\
\hline
\end{tabular}

* Not corrected using response factors.

for the $\mathrm{P} 2$ polysaccharide is shown in Table 1 . The crude preparation shows the presence of the linkages $t-$ mannose; t-glucose; 1,2-mannose; 1,4-glucose; 1,3,4glucose and 1,2,6-mannose. CTAB purification eliminates t-mannose and 1,2,6-mannose, and reduces the content of 1,2-mannose. This can be explained by the removal of the neutral mannan material. The linkage analysis following carboxy reduction reveals the presence of 1,4-glucuronic acid due to the appearance of deuterated 1,4,6-glucose residues. No t-rhamnose residues were detected but there is a t-Glc residue instead. These conclusions are consistent with the proposed repeat unit shown in Fig. 1c. The basic carbohydrate repeat unit is a pentameric structure. The polysaccharide consists of a cellulosic backbone substituted on every second glucose residue with a charged trisaccharide side-chain terminating in a glucose residue. These data are consistent with the production of acetan by strain CKE5 and the production of a truncated acetan structure by strain P2. They demonstrate that disruption of aceP alters the structure of the extracellular polysaccharide, and the chemical analysis is consistent with formation of a truncated pentameric rather than heptameric repeat unit. The chromatograms for the CTAB-purified P2 and acetan are shown in Fig. 4. The experimental retention times on the columns are dependent on the detailed operating conditions and need to be corrected on the basis of known standards (not shown in Fig. 4). The relative retention times and massspectrometric data are used to assign the peaks. The linkage analysis of the $\mathrm{P} 2$ polysaccharide using the reductive cleavage method (Table 1) was particularly useful for several reasons. Firstly, it confirmed the linkage pattern revealed by conventional methylation analysis. Secondly, the retention times of the 1,5anhydroalditol derivatives are distinct and identify the terminal sugar unambiguously as t-glucose. Thirdly, it also confirms the rings as pyranoses [except for glucuronic acid which rearranges to the furanose form during reductive cleavage (Vodonik \& Gray, 1988)]. 


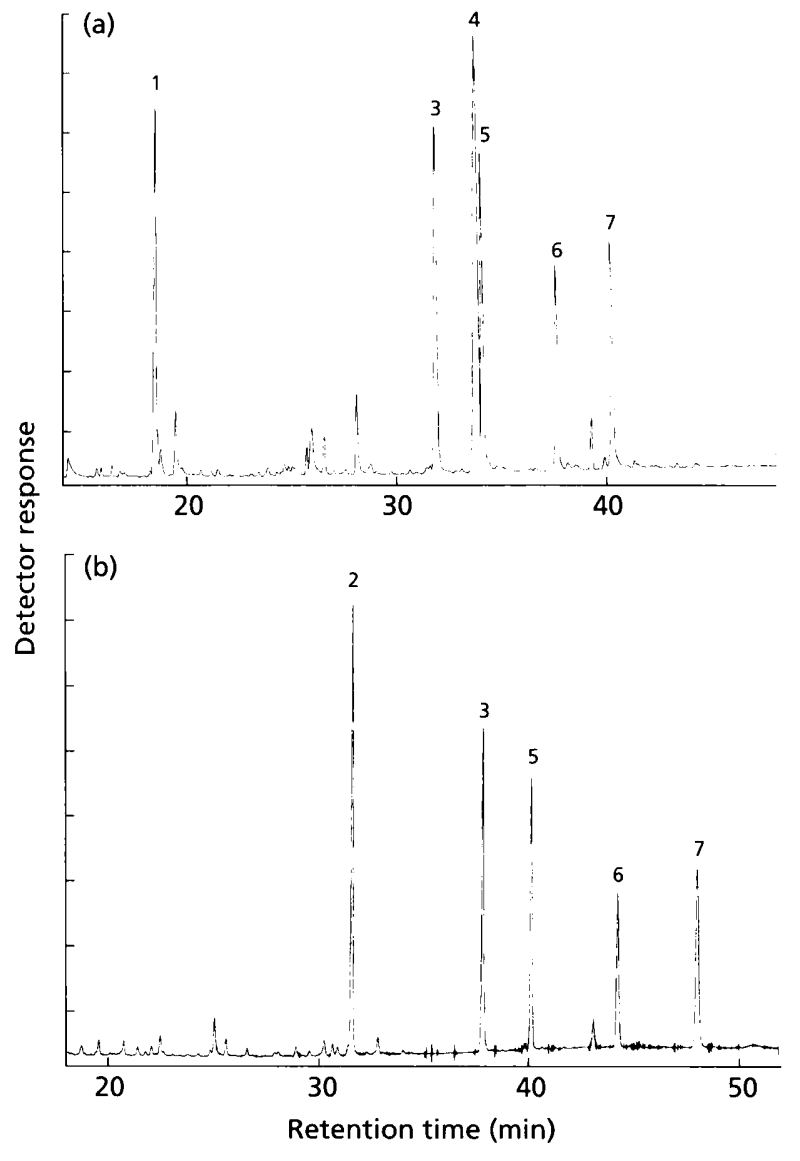

Fig. 4. Gas chromatograms of the PMAAs of CTAB-purified (a) acetan (Ojinaka et al., 1996) and (b) P2 polysaccharide. The PMAAs correspond to the following sugar residues: $1, t-$ rhamnose; 2, t-glucose; 3, 1,2-mannose; 4, 1,6-glucose; 5, 1,4glucose; 6, 1,3,4-glucose; 7, 1,4-glucuronic acid. The GC column was replaced between the two runs shown in (a) and (b), explaining the difference in retention time for equivalent residues. Identification of particular residues is based on the use of standards and mass spectrometric data.

\section{DISCUSSION}

Genetic manipulation of Acetobacter strains is widely known to be impaired by the low frequencies of transformation experienced with this species. In our case, the problems could not be overcome using procedures reported to be successful in other strains (Fukaya et al., 1985; Valla et al., 1986; Inoue et al., 1985; Hall et al., 1992; Wong et al., 1990). In addition, the problem did not seem to be related to the presence of a restrictionmodification system as described by Petroni et al. (1996) and Coucheron (1998), since plasmid DNA prepared from strain $\mathrm{C} 1$ did not result in higher electrotransformation frequencies of strain $\mathrm{C} 1$ when compared to frequencies obtained using DNA isolated from Escherichia coli (data not presented). The 10000-fold increase in electrotransformation frequency obtained with strain CKE5 compared to that of the wild-type and mutagenized strains was an essential prerequisite to the use of a suicide delivery vehicle for gene disruption experiments. The basis of this increased frequency is unclear and may indicate that individual transformants (before curing) represented mutants with an enhanced ability to take up DNA. However, there are reports in the literature that many strains of Acetobacter contain cryptic plasmids, which may be incompatible with an incoming plasmid. Such a plasmid could also have been lost during the plasmid-curing regime. Although no cryptic plasmids were detected in our strain $\mathrm{C} 1$, we cannot rule out the possibly of one existing. Analysis of the polysaccharide produced by strain CKE 5 confirmed that acetan biosynthesis was not altered by the mutagenesis or plasmid-curing procedure, making it ideally suitable for genetic manipulation studies.

AceP displayed a characteristic conserved motif in the $\mathrm{N}$-terminal region, common to $\beta$-glycosyltransferases that use an $\alpha$-linked nucleotide diphospho-sugar donor (in this case $\alpha, D-U D P$-glucose) in the transfer of the sugar to an acceptor (the growing repeat unit) to form a $\beta$-linked product (Saxena et al., 1995; Becker et al., 1998). These enzymes are members of the 'inverting' family of glycosyl transferases, as the reaction proceeds via inversion of the anomeric configuration at the reaction centre where a single nucleophilic substitution at the anomeric centre is sufficient to generate the $\beta$ configuration (Sinnott, 1990; Saxena et al., 1995). That AceP had a higher identity with ExoO and ExoU from Sinorhizobium meliloti than to AceA and AceB from the acetan pathway in A. xylinum led to the prediction that it catalyses the transfer of a $\beta$-D-glucose $1 \rightarrow 6$ linked glucose; i.e. step 6 of the acetan pathway involving linkage to a $\beta$-D-glucose linked $1 \rightarrow 4$ to $\beta$-D-glucuronic acid (Fig. 1a). Interestingly, ExoO, to which AceP had highest identity, also transfers a $1 \rightarrow 6$-linked $\beta$-D-glucose to $\beta$-D-glucose- $(1 \rightarrow 4)$-glucuronic acid in the growing succinoglycan chain. It is tempting to speculate that the specificity of these transferase enzymes may be influenced not only by the sugar composition of the acceptor residue, but also by the micro-environment in which that residue is found. If this is found to be true, it could have important implications for genetic manipulation of EPS structure by heterologous gene expression.

Disruption of aceP confirmed the function predicted from the homology studies above. The disruption strategy did not result in polar effects on the expression of the acetan operon, since expression of the downstream genes ace $A$, ace $B$ and aceC (Fig. 3) encoding transferases I, II and III, respectively (Griffin et al., 1996a, b), was unaffected. Surprisingly, the yield of crude EPS obtained from the aceP mutant strain (P2) was close to that produced by wild-type strains. In our previous study, crude yields of a novel acetan-based polymer produced by strain CR $1 / 4$ were only $33 \%$ of those of the parent acetan-producing strain (MacCormick et al., 1993); purified yields were approximately $10 \%$ of the parent yields (M. Ridout, pers. comm.). Others have also reported the yields as low as $1 \%$ those of wild-type for strains synthesizing novel polymers (Vanderslice et al., 1990). Thus disruption of targeted genes may only influence polysaccharide as- 
sembly and perhaps not affect the level of polysaccharide produced.

The results of the chemical analysis of the polysaccharide from the CKE5 strain are consistent with the production of acetan by this strain. The P2 polysaccharide, however, is clearly identified as being chemically distinct from that produced by the parent CKE5. The linkage analysis of CTAB-purified P2 polymer shows all the sugar residues expected to be present if the acetan has been truncated at the 1)- $\alpha$-Dglucose-(6-1)- $\downarrow-\beta$-D-glucose glycosidic linkage. This is consistent with blocking the biosynthetic pathway at transferase 6. Full structural characterization of the P2 polymer by NMR is under way to confirm the proposed structure by determining the sequence of sugars and the non-carbohydrate substitution of this novel polymer.

All possible variants of the acetan structure can be genetically engineered in this system for use in analysis of the polysaccharide structure-function relationship. In the longer term, heterologous gene expression could be used to engineer novel sugars or linkages in the acetan repeat unit.

\section{ACKNOWLEDGEMENTS}

This work was funded by the Biotechnology and Biological Sciences Research Council.

\section{REFERENCES}

Altschul, S. F., Gish, W., Miller, W., Myers, E. W. \& Lipman, D. J. (1990). Basic local alignment search tool. J Mol Biol 215, 4(13-410.

Baird, J. K. \& Smith, W. W. (1989). An analytical procedure for gellan gum in food gels. Food Hydrocolloids 3, 407-411.

Becker, A., Kleickmann, A., Keller, M., Arnold, W. \& Puhler, A. (1993). Identification and analysis of the Rhizobium meliloti exoAMONP genes involved in exopolysaccharide biosynthesis and mapping of promoters located on the exoHKLAMONP fragment. Mol Gen Genet 241, 367-379.

Becker, A., Ruberg, S., Kuster, H., Roxlau, A. A., Keller, M., Ivashina, T., Cheng, H.-P., Walker, G. C. \& Puhler, A. (1998). The 32-kilobase exp gene cluster of Rhizobium meliloti directing the biosynthesis of galactoglucan: genetic organization and properties of the encoded genes. J Bacteriol 179, 1375-1384.

Betlach, M. R., Capage, M. A., Doherty, D. H., Hassler, R. A., Henderson, N. M., Vanderslice, R. W., Marrelli, J. D. \& Ward, M. B. (1987). Genetically engineered polymers: manipulation of xanthan biosynthesis. In Industrial Polysaccharides: Genetic Engineering, Structu/Property Relations and Applications, pp. 35-50. Fdited by M. Yalpani. Amsterdam: Elsevier.

Carpita, N. C. \& Shea, E. M. (1989). Linkage structure of carbohydrates by gas chromatography-mass spectrometry (GC-MS) of partially methylated alditol acetates. In Analysis of Carbohydrates by Gas-Liquid Chromatography and Mass Spectrometry, pp. 157-216. Edited by C. J. Biermann \& G. D. McGinnis. Boca Raton, FL: CRC Press.

Close, T. J., Zaitlin, D. \& Kado, C. I. (1984). Design and development of amplifiable broad-host-range cloning vectors: analysis of the vir region of Agrobacterium tumefaciens plasmid pTIC58. Plasmid 12, 111-118.

Coucheron, D. H. (1998). Acetobacter strains contain DNA modified at GAATTC and GANTC. Can J Microbiol 43, 456-460.

Devereux, J., Haeberli, P. \& Smithies, O. (1984). A comprehensive set of sequence analysis programs for the Vax. Nucleic Acids Res 12, 216-223.

Dische, Z. \& Shettles, L. B. (1948). A specific color reaction of methylpentoses and a spectrophotometric micromethod for their detection. J Biol Chem 175, 595-603.

Doares, S. H., Albersheim, P. \& Darvill, A. G. (1991). An improved method for the preparation of standards for glycosyl-linkage analysis of complex carbohydrates. Carbohydr Res 210, 311-317.

Dubois, M., Gilles, K. A., Hamilton, J. K., Roberts, P. A. \& Smith, F. (1956). Colorimetric method for the determination of sugars and related substances. Anal Chem 28, 350-356.

Filisetti-Cozzi, T. M. C. C. \& Carpita, N. C. (1991). Measurement of uronic acids without inference from neutral sugars. Anal Biochem 197, 157-162.

Fukaya, M., Tayama, K., Okumura, H., Masai, H., Uozumi, T. \& Beppu, T. (1985). Improved transformation method for Acetobacter with plasmid DNA. Agric Biol Chem 7, 2091-2097.

Glucksmann, M. A., Reuber, T. L. \& Walker, G. C. (1993). Family of glycosyl transferases needed for the synthesis of succinoglycan by R hizobium meliloti. J Bacteriol 175, 7033-7044.

Gray, G. R. (1990). Linkage analysis using the reductive cleavage method. Methods Enzymol 193, 573-587.

Griffin, A. M., Edwards, K. J., Gasson, M. J. \& Morris, V. J. (1995). Identification of structural genes involved in bacterial exopolysaccharide production. Biotechnol Genet Eng Rev 13, 1-18.

Griffin, A. M., Morris, V. J. \& Gasson, M. J. (1996a). Genetic analysis of the acetan biosynthetic pathway in Acetobacter xylinum: nucleotide sequence of the ace $B$, ace $C$, ace $D$ and ace $E$ genes. DNA Seq-J DNA Seq Map 6, 275-284.

Griffin, A. M., Morris, V. J. \& Gasson, M. J. (1996b). Identification, cloning and sequencing the aceA gene involved in acetan biosynthesis in Acetobacter xylinum. FEMS Microbiol Lett 137, 115-121.

Griffin, A. M., Edwards, K. J., Morris, V. J. \& Gasson, M. J. (1997a). Genetic analysis of acetan biosynthesis in Acetobacter xylinum: DNA sequence analysis of the aceM gene encoding an UDPglucose dehydrogenase. Biotechnol Lett 19, 469-474.

Griffin, A. M., Poelwijk, E. S., Morris, V. J. \& Gasson, M. J. (1997b). Cloning of the aceF gene encoding the phosphomannose isomerase and GDP-mannose pyrophosphorylase activities involved in acetan biosynthesis in Acetobacter xylinum. FEMS Microbiol Lett 154, 389-396.

Hall, P. E., Anderson, S. M., Johnston, D. M. \& Cannon, R. E. (1992). Transformation of Acetobacter xylinum with plasmid DNA by electroporation. Plasmid 28, 194-200.

Hassler, R. A. \& Doherty, D. H. (1990). Genetic engineering of polysaccharide structure: production of variants of xanthan gum in Xanthomonas campestris. Biotechnol Programme 6, 182-187.

Hestrin, S. \& Schramm, M. (1954). Synthesis of cellulose by Acetobacter xylinum. 2. Preparation of freeze-dried cells capable of polymerizing glucose to cellulose. Biochem J 58, 345-352.

Higgins, D. G. (1994). CLUSTAL v : multiple alignment of DNA and protein sequences. In Computer Analysis of Sequence Data, part 2, pp. 307-318. Edited by A. M. Griffin \& H. G. Griffin. Totowa, $\mathrm{NJ}$ : Humana Press.

de lannino, N. I., Couso, R. O. \& Dankert, M. A. (1988). Lipidlinked intermediates and the synthesis of acetan in Acetobacter xylinum. J Gen Microbiol 134, 1731-1736. 
Inoue, T., Fukuda, M. \& Yano, K. (1985). Efficient introduction of vector plasmids into acetic acid bacteria. J Ferment Technol 63, $1-4$

Kenne, L. \& Lindberg, B. (1983). Bacterial polysaccharides. In The Polysaccharides, vol. 2, pp. 287-363. Edited by G. O. Aspinall. New York: Academic Press.

Klokman, M. A. B., Wakarchuk, W., Nuijten, P. J. M. \& van der Zeijst, B. A. M. (1997). Capsular polysaccharide synthesis in Streptococcus pneumoniae serotype 14: molecular analysis of the complete $c p s$ locus and identification of genes encoding glycosyltransferases required for the biosynthesis of the tetrasaccharide subunit. Mol Microbiol 26, 197-208.

Lindberg, B. (1990). Components of bacterial polysaccharides. Adv Carbohydr Chem Biochem 48, 279-318.

MacCormick, C. A., Harris, J. E., Gunning, A. P. \& Morris, V. J. (1993). Characterization of a variant of the polysaccharide acetan produced by a mutant of Acetobacter xylinum strain CR1/4. J Appl Bacteriol 74, 196-199.

MacCormick, C. A., Harris, J. E., Jay, A. J., Ridout, M. J., Colquhoun, I. J. \& Morris, V. J. (1996). Isolation and characterization of a new extracellular polysaccharide from an Acetobacter species. J Appl Bacteriol 81, 419-424.

Ness, R. K., Fletcher, H. G. \& Hudson, C. S. (1950). The reduction of acetylated glycopyranosyl bromide to 1,5-anhydroglycitols with lithium aluminium hydride 1,5-anhydro rhamnitol. J Am Chem Soc 72, 4547-4549.

Ojinaka, C., Jay, A. J., Colquhoun, I. J., Brownsey, G. J., Morris, E. R. \& Morris, V. J. (1996). Structure and conformation of acetan polysaccharide. Int J Biol Macromol 19, 149-156.

Pearson, W. R. (1994). Using the FASTA program to search protein and DNA sequence databases. In Computer Analysis of Sequence Data, part 1, pp. 307-331. Edited by A. M. Griffin \& H. G. Griffin. Totowa, NJ: Humana Press.

Petroni, E. A., Bocca, S. N. \& llepi, L. (1996). Sequence-specific DNA modification in Acetobacter xylinum. Cell Mol Biol 42, 759-767.

Reuber, T. L. \& Walker, G. C. (1993). Biosynthesis of succinoglycan, a symbiotically important exopolysaccharide of Rbizobium meliloti. Cell 74, 269-280.

Rolf, D., Bennek, J. A. \& Gray, G. R. (1985). Analysis of linkage positions in D-glucopyranosyl residues by the reductive cleavage method. Carbohydr Res 137, 183-196.

Roller, S. \& Dea, I. C. M. (1992). Biotechnology in the production and modification of biopolymers in foods. Crit Rev Biotechnol 12 , 261-277.

Sambrook, J., Fritsch, E. F. \& Maniatis, T. (1989). Molecular Cloning: a Laboratory Manual. Cold Spring Harbor, NY: Cold Spring Harbor Laboratory.

Saxena, I. A., Brown, R. M., Jr, Fevre, M., Geremia, R. A. \& Henrissat, B. (1995). Multidomain architecture of $\beta$-glycosyl transferases: implications for mechanisms of action. J Bacteriol 177, 1419-1424.

Sievers, M., Ludwig, W. \& Teuber, M. (1994). Phylogenetic positioning of Acetobacter, Gluconobacter, Rbodopila and Acidiphilum species as a branch of Acidophilic bacteria in the $\alpha$ subclass of Proteobacteria based on $16 \mathrm{~S}$ ribosomal DNA sequences. Syst Appl Microbiol 17, 189-196.

Sinnott, M. L. (1990). Catalytic mechanisms of enzymatic glycosyl transfer. Chem Rev 90, 1171-1202.

Sutherland, I. W. (1998). Novel and established applications of microbial polysaccharides. Trends Biotechnol 16, 41-46.

Valla, S., Coucheron, D. H. \& Kjosbakken, J. (1986). Conjugative transfer of the naturally-occurring plasmids of Acetobacter xylinum by IncP-plasmid-mediated mobilization. J Bacteriol 165 , 336-339.

Vanderslice, R. W., Doherty, D. H., Capage, M. A., Betlach, M. R., Hassler, R. A., Henderson, N. M., Ryan-Graniero, J. \& Tecklenburg, M. (1990). Genetic engineering of polysaccharide structure in Xanthomonas campestris. In Biomedical and Biotechnological Advances in Industrial Polysaccharides, pp. 145-156. Edited by V. Cresenzi, I. C. M. Dea, S. Paoletti, S. S. Stivala \& I. W. Sutherland. New York: Gordon and Breach Science Publications.

Vodonik, S. A. \& Gray, G. R. (1988). Analysis by the reductivecleavage method of linkage positions in a polysaccharide containing 4-linked D-glucopyranosyluronic acid residue. Carbohydr Res 175, 93-102.

Wong, H. C., Fear, A. L., Calhoon, R. D. \& 10 other authors (1990). Genetic organisation of the cellulose synthase operon in Acetobacter xylinum. Proc Natl Acad Sci USA 87, 8130-8134.

York, W. S., Darvill, A. G., McNeil, M., Stevenson, T. T. \& Albersheim, P. (1985). Isolation and characterization of plant cell walls and cell wall components. Methods Enzymol 118, 3-40.

Received 29 January 1999; revised 1 March 1999; accepted 11 March 1999. 